\title{
Simplified organ cultures of human embryo trachea in the diagnosis of viral respiratory disease of children
}

\author{
A. P. C. H. ROOME, VALERIE DICKINSON, AND E. O. CAUL \\ From the Virology Laboratory, Bristol Royal Hospital for Sick Children, Bacteriology Department, \\ Bristol University Medical School, and Virology Department, Bristol Public Health Laboratory
}

SYNOPSIS Organ cultures of human embryonic trachea in test tubes were used as an adjunct to tissue cultures in the isolation of respiratory viruses from children in hospital. Fifty-one viruses were obtained from 127 specimens, giving an isolation rate of $40 \%$. Fifteen viruses were isolated from the original tissue cultures and also after passage through organ culture. Thirty viruses were isolated from the original tissue culture only, and six viruses only from organ culture (three parainfluenza, one influenza $\mathrm{A}$, and one rhinovirus). An increase of $5 \%$ in virus isolation rate over that of standard tissue culture was obtained.

Since it was shown by Hoorn (1964) and Hoorn and Tyrrell (1965) that many respiratory viruses grew to a high titre in organ cultures of human foetal nasal and tracheal epithelium, this technique has been applied to the study of clinical material (Higgins, 1966; Tyrrell and Bynoe, 1966).

Most methods of organ culture require the use of petri dishes, and either incubation in an atmosphere of carbon dioxide or frequent changes of medium. They are time-consuming and unsuitable for the small general virology laboratory.

In 1968 Harnett and Hooper described a simplified method of organ culture in which fragments of tracheal epithelium were rolled in tissue culture tubes instead of being maintained in petri dishes. They compared the isolation rate of respiratory viruses in monolayer tissue cultures with that obtained in the same tissue cultures after prior passage through their organ culture system. The increase in isolation rate they obtained $(8 \%)$ was similar to the increase in isolation rate obtained by Higgins, who used the more elaborate petri dish organ culture system, in patients of the same age group. No direct comparison of the two methods of organ culture inoculated with the same specimens has been made.

We used a modification of Harnett and Hooper's method (Butler, 1969; Cherry and Taylor-Robinson, 1970 ) in conjunction with standard monolayer tissue cultures to see whether a significant increase in isolation rate could be achieved in an unselected series Received for publication 29 October 1970. of children with acute respiratory disorders admitted to a children's hospital.

\section{Materials and Methods}

All children admitted to the hospital with acute respiratory infections were examined for virus excretion, and swabs from 127 of these were inoculated into organ cultures and tissue cultures between September 1969 and April 1970.

Patients were seen by a member of the laboratory staff within 24 hours of admission, when duplicate nose and throat swabs were taken. One nose and one throat swab were inoculated directly into HeLa and monkey kidney monolayer tissue cultures at the bedside, and the other paired swabs were broken off into a bijou bottle containing $4 \mathrm{ml}$ of milk/saline transport medium without antibiotics. This constituted the specimen.

These specimens were kept at room temperature until inoculation, nearly always within one hour of collection, into further types of culture in the laboratory.

Cultures inoculated in the laboratory were the WI.38 strain of semi-continuous diploid human embryo lung fibroblasts, primary or low passage skin-muscle human embryo fibroblasts, primary human embryo kidney, and organ cultures. When human embryo kidney cells were not available, specimens were stored at $-40^{\circ} \mathrm{C}$ and inoculated later. 
PREPARATION OF ORGAN CULTURES

The tracheas were dissected out from human embryos of 12-26 weeks' gestation and were placed in a petri dish, washed twice in phosphate-buffered saline, and all remnants of connective tissue removed.

In preliminary experiments we found it extremely difficult to view ciliary movement of small tracheal blocks by direct microscopy. We therefore used complete tracheal cross-sections about $1 \mathrm{~mm}$ thick, cut carefully with a scalpel to avoid damage to the ciliated epithelium. Each foetus yielded an average of 10 tracheal rings.

Each tracheal ring was placed into a $4 \times \frac{1}{2}$ in. tissue culture tube with $1 \mathrm{ml}$ of Eagle's basal medium with $0.7 \%$ sodium bicarbonate solution, but no serum.

The tracheal rings could easily be made to adhere to the wall of the tube and ciliary movement was observed under the low power of the microscope. Organ cultures were given a change of medium the day after preparation and before inoculation with the clinical specimen within five days of preparation. Any cultures not showing strong ciliary activity were discarded.

The cultures were incubated in a roller drum at $33^{\circ} \mathrm{C}$. After five to seven days they were observed for ciliary motility and the culture fluid was passed into HeLa, monkey kidney, WI.38, and human embryo kidney tissue cultures. If necessary the remaining organ culture fluid was frozen and stored until human embryo kidney culture became available.

\section{MAINTENANCE OF TISSUE CULTURES}

Inoculated cells of the Bristol line of HeLa cells were maintained with $4 \%$ rabbit serum for 28 days stationary at $35^{\circ} \mathrm{C}$ and observed daily for cytopathic effect.

All other tissue cultures were incubated in a roller drum at $33^{\circ} \mathrm{C}$.

\section{Monkey kidney}

Monkey kidney cultures were either primary cynomolgus (Burroughs Wellcome) or secondary Rhesus (MRC Hampstead Laboratories). Before use, tubes were washed three times with phosphatebuffered saline and replaced with $1 \mathrm{ml}$ of medium ' 199 ' containing $4 \%$ milk saline. Cultures were examined every two days for cytopathic effect and tested for haemadsorption three times at five-day intervals using guinea pig erythrocytes. They were discarded at 15 days.

\section{Low passage human embryo fibroblasts}

These were prepared from human embryo skin/ muscle or whole embryo, and maintained with $2 \%$ calf serum.
Cultures were kept for four weeks after inocula- $\underline{\bar{\sigma}}$ tion and observed every two or three days for cytopathic effect.

Semi-continuous diploid embryo fibroblasts (WI.38 cells)

These cells were obtained from the MRC Labora- $\overparen{\mathbb{D}}$ tories, Hampstead. Cells were examined daily for cytopathic effect for 14 days before being discarded.

\section{Primary human embryo kidney}

These cells were maintained with $2 \%$ calf serum. They were examined daily for cytopathic effect and discarded after 14 days.

IDENTIFICATION OF VIRUSES

Preliminary identification was by cytopathic effect.

Myxoviruses were identified as influenza by

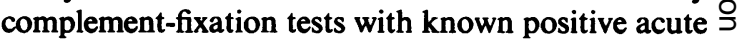
and convalescent sera. Acid stability tests were $\vec{\phi}$ carried out on picornaviruses and further identifica- $\mathbb{D}$ tion of picornaviruses, paramyxoviruses, herpes simplex, and adenoviruses was by neutralization 3 with sera provided by the Standards Laboratory of $\stackrel{\mathbb{D}}{-}$ the Central Public Health Laboratory, Colindale. Cytomegalovirus was identified by cytopathic effect, the presence of inclusion bodies, and inability to produce a cytopathic effect in HeLa cells.

\section{Results}

The 127 specimens yielded a total of 51 viruses, $\stackrel{\circ}{\mathbb{Q}}$ giving an isolation rate of $40 \%$ (Table I). Altogether, five major virus groups - the myxoviruses, paramyxoviruses, picornaviruses, herpes and adenovirus group-were represented, and individual virus types isolated totalled 15. An outbreak of influenza caused by influenza virus $A_{2}$, Hong Kong variant, occurred during the survey and accounted for 17 of the viruses isolated; the others represent a wide-crosssection of viruses associated with respiratory disease. $\delta$

Owing to the small numbers of any single virus type isolated, it is difficult to deduce any valid $ᄋ$ information about the persistence of ciliary move- $\rightarrow$ ment in the organ cultures at the end of the incubation time (Table II). Four organ cultures from which parainfluenza virus type 3 was isolated were all still $\Omega$ beating after five days' incubation, whilst out of a $N$

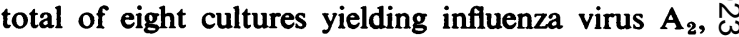
four were still beating after a similar period. Only $\sigma$ six viruses, which had not been isolated in the 0 original tissue cultures, were isolated after passage $\frac{\overparen{D}}{\Phi}$ through organ culture: three parainfluenza type $3, \stackrel{?}{\rightarrow}$ two influenza $A$, and one rhinovirus ' $H$ '. Thus the $\square$ isolation rate without organ culture was $35 \%$, giving an additional isolation rate of only $5 \%$ with organ culture. 


\begin{tabular}{|c|c|c|c|c|c|c|c|c|c|c|c|c|c|c|c|}
\hline & $\begin{array}{l}\text { In- } \\
\text { fluenza } \\
A\end{array}$ & $\begin{array}{l}\text { Parain- } \\
\text { fluenza } \\
3\end{array}$ & Mumps & $\begin{array}{l}\text { Meas- } \\
\text { les }\end{array}$ & $\begin{array}{l}\text { Respi- } \\
\text { ratory } \\
\text { Syn- } \\
\text { cytial }\end{array}$ & $\begin{array}{l}\text { Rhino- } \\
\text { virus } \\
\text { 'H' }\end{array}$ & $\begin{array}{l}\text { Rhino- } \\
\text { virus } \\
\text { 'M' }\end{array}$ & $\begin{array}{l}E C H O \\
6\end{array}$ & $\begin{array}{l}\mathrm{ECHO} \\
7\end{array}$ & $\begin{array}{l}\mathrm{ECHO} \\
9\end{array}$ & $\begin{array}{l}\text { Un- } \\
\text { identi- } \\
\text { fied } \\
\text { Entero- } \\
\text { virus }\end{array}$ & $\begin{array}{l}\text { Cyto- } \\
\text { megalo- } \\
\text { virus }\end{array}$ & $\begin{array}{l}\text { Herpes } \\
\text { Sim- } \\
\text { plex }\end{array}$ & $\begin{array}{l}\text { Adeno- } \\
\text { virus }\end{array}$ & Total \\
\hline $\begin{array}{l}\text { Isolated in tissue } \\
\text { culture and organ } \\
\text { culture }\end{array}$ & 6 & 1 & 2 & 1 & 0 & 0 & 0 & 0 & 1 & 0 & 0 & 0 & 0 & 4 & 15 \\
\hline $\begin{array}{l}\text { Isolated in tissue } \\
\text { culture only }\end{array}$ & $9^{1}$ & 1 & 2 & 0 & 8 & 2 & 1 & 1 & 0 & 1 & 1 & 2 & 1 & 1 & 30 \\
\hline $\begin{array}{l}\text { Jsolated in organ } \\
\text { culture only }\end{array}$ & 2 & 3 & 0 & 0 & 0 & 1 & 0 & 0 & 0 & 0 & 0 & 0 & 0 & 0 & 6 \\
\hline Total & 17 & 5 & 4 & 1 & 8 & 3 & 1 & 1 & 1 & 1 & 1 & 2 & 1 & 5 & 51 \\
\hline
\end{tabular}

Table I Comparison of isolation of viruses with and without passage through tracheal organ culture

${ }^{1}$ Three organ cultures infected with antibiotic-resistant bacteria where influenza $A_{2}$ virus isolated in tissue culture.

\begin{tabular}{ll}
\hline Virus & Cilia Beating/Total \\
\hline Parainfluenza 3 & $4 / 4$ \\
Influenza A & $4 / 8$ \\
Rhinovirus H & $1 / 1$ \\
Mumps & $2 / 2$ \\
Measles & $0 / 1$ \\
Adenovirus I & $1 / 1$ \\
Adenovirus II & $1 / 3$ \\
ECHO 7 & $1 / 1$ \\
\hline
\end{tabular}

Table II Viruses isolated in organ culture showing number with cilia still beating at the end of incubation

${ }^{1}$ Control uninoculated cultures from same foetus were still beating at end of 5-7 days' incubation.

\section{Discussion}

The work of Hoorn $(1964,1966)$, Hoorn and Tyrrell (1965), and Tyrrell and Hoorn (1965) showed that a selection of enteroviruses, adenoviruses, and herpes simplex grew well in tracheal organ cultures and that the growth of influenza and parainfluenza viruses was enhanced. Only respiratory syncytial virus from clinical specimens was found to grow poorly by this method. Tyrrell and Bynoe (1965), Tyrrell, Bynoe, and Hoorn (1968) and Higgins (1966) found that organ cultures greatly enhanced the isolation rate of rhinoviruses and this technique is the only method for isolating certain coronaviruses (McIntosh, Dees, Becker, Kapikian, and Chanock, 1967).

All the work mentioned above was carried out using petri dish methods of organ culture, and Votova and Tyrrell (1970), using Harnett and Hooper's method, found that this simplified system was $\mathbf{1 0 0}$ times more sensitive than tissue cultures for growing a rhinovirus. Growth of parainfluenza virus 2 was also enhanced, while there was little difference between the sensitivity of this method and standard monkey kidney culture in the case of influenza $B$.
Tyrrell (1970) makes the generalization that any respiratory virus multiplies in organ cultures of human embryonic respiratory epithelium and this applies both to laboratory strains and also to viruses present in clinical specimens. Higgins et al (1969) compared standard methods of virus isolation with the same methods after passage of the clinical specimens through organ cultures in petri dishes. They found that a greater number of enteroviruses, herpes simplex, and mumps viruses were isolated by the standard methods than in organ culture. In the case of rhinoviruses as many grew only by standard methods as were isolated only after passage through organ culture. They suggested that organ cultures might best be reserved for specimens failing to yield viruses by standard tissue culture methods.

Our results, like those of Higgins et al, are also rather disappointing. The only virus we have clearly demonstrated to have an increased isolation rate by use of organ culture is parainfluenza type 3. Many other respiratory viruses were isolated in tissue culture and not in organ culture. Few rhinoviruses were isolated but infection with these viruses is unlikely to account for a significant number of hospital admissions of children.

Harnett and Hooper maintained their organ cultures for only five to seven days before passing fluids into tissue culture. Tyrrell and Blamire (1967), using a miniaturized system of organ culture in petri dishes, obtained high titres of rhinoviruses and influenza B in a single fluid collected four days after inoculation. In our case longer incubation with frequent changes of medium might have given better results with some viruses but this would probably have been outweighed by inactivation of other viruses.

The growth of all eight respiratory syncytial viruses in tissue culture only confirms the finding of 
Hoorn (1966) that this virus does not grow well in organ cultures. Furthermore, organ cultures were not inoculated at the bedside, although $\mathrm{HeLa}$ cultures were, and this is a very labile virus.

\section{Conclusion}

The method described is not a satisfactory adjunct to tissue culture when attempting to isolate a wide cross-section of viruses, although it has certain advantages for the detection of rhinoviruses and parainfluenza viruses. Since all organ culture fluids had to be passed into the full range of monolayer tissue cultures used for primary isolation (except human embryo fibroblasts), the doubling of the work load produced a $5 \%$ increase in isolation rate.

We should like to thank Dr Suzanne K. R. Clarke and Dr P. G. Higgins for their help and encouragement with this paper; Dr C. M. P. Bradstreet for the supply of diagnostic reagents; Dr F. T. Perkins for the supply of tissue cultures; Drs J. Apley, D. Burman, Professor N. R. Butler, Drs Beryl Corner and W. H. Schutt, and the medical and nursing staff of the Bristol Royal Hospital for Sick Children for their assistance and cooperation.

\section{References}

Butler, M. (1969). Isolation and growth of mycoplasma in human embryo tracheal cultures. Nature (Lond.), 224, 605-606.

Cherry, J. D., and Taylor-Robinson, D. (1970). Large-quantity production of chicken embryo tracheal organ cultures and use in virus and mycoplasma studies. Appl. Microbiol., 19, 658-662. 음

Harnett, G. B., and Hooper, W. L. (1968). Test-tube organ cultures:of ciliated epithelium for the isolation of respiratory viruses. Lancet, 1, 339-340.

Higgins, P. G. (1966). The isolation of viruses from acute respiratory음 infections. Part V. The use of organ cultures of human embryonic nasal and tracheal ciliated epithelium. Mth. Bull. Minist. Hlth Lab. Serv., 25, 283-288.

Higgins, P. G., Ellis, E. M., and Woolley, D. A. (1969). A comparative $\overparen{D}$ study of standard methods and organ culture for the isolation of respiratory viruses. J. med. Microbiol., 2, 109-115. Uి

Hoorn, B. (1964). Respiratory viruses in model experiment: Acta oto-laryng., Suppl. 188, 138-144.

Hoorn, B. (1966). Organ cultures of ciliated epithelium for the study of respiratory viruses. Acta path. microbiol. scand., 66, Suppl. $\vec{\omega}$ $183,1-37$

Hoorn, B., and Tyrrell, D. A. J. (1965). On the growth of certain 'newer' respiratory viruses in organ cultures. Brit. J. exp. Path., 46, 109-118.

Hoorn, B., and Tyrrell, D. A. J. (1969). Organ cultures in virology. Progr. med. Virol., 11, 408-450.

McIntosh, K., Dees, J. H., Becker, W. B., Kapikian, A. Z., and it Chanozk, R. M. (1967). Recovery in tracheal organ cultures $\infty$ of novel viruses from patients with respiratory disease. Proc. nat. Acad. Sci. (Wash.), 57, 933-940.

Tyrrell, D. A. J. (1970). Hunting common cold viruses by some new methods. J. infect. Dis., 121, 561-571.

Tyrrell, D. A. J., and Blamire, C. J. (1967). Improvements in a method $\overparen{(}$ of growing respiratory viruses in organ cultures. Br. J. exp. 웅 Path., 48, 217-227.

Tyrrell, D. A. J., and Bynoe, M. L. (1965). Cultivation of a novel $\frac{D}{3}$ type of common cold virus in organ cultures. Br. med. J., 1, 요
$1467-1470$.

Tyrrell, D. A. J., and Bynoe, M. L. (1966). Cultivation of viruses from $\overrightarrow{0}$ a high proportion of patients with colds. Lancet, 1, 76-77.

Tyrrell, D. A. J., Bynoe, M. L., and Hoorn, B. (1968). Cultivation of $\longrightarrow$ 'difficult' viruses from patients with common colds. $\mathrm{Br}$. med. J., 1, 606-610.

Tyrrell, D. A. J., and Hoorn, B. (1965). The growth of some myxoviruses in organ cultures. Br.J. exp. Path., 46, 514-518.

Votava, M., and Tyrrell, D. A. J. (1970). The possible value of certain $\bar{O}$ cells for the propagation of respiratory viruses. Arch. ges. Оి Virusforsch., 29, 253-256. 